\title{
AGE, GROWTH, AND REPRODUCTIVE BIOLOGY OF TURBOT, SCOPHTHALMUS MAXIMUS (ACTINOPTERYGII: PLEURONECTIFORMES: SCOPHTHALMIDAE), FROM THE SOUTH-WESTERN COASTS OF BLACK SEA, TURKEY
}

\author{
Lütfiye ERYILMAZ* and Cem DALYAN
}

Department of Biology, Faculty of Science, Istanbul University, Istanbul, Turkey

\begin{abstract}
Eryilmaz L., Dalyan C. 2015. Age, growth, and reproductive biology of turbot, Scophthalmus maximus (Actinopterygii: Pleuronectiformes: Scophthalmidae), from the south-western coasts of Black Sea, Turkey. Acta Ichthyol. Piscat. 45 (2): 181-188.
\end{abstract}

\begin{abstract}
Background. The turbot, Scophthalmus maximus (Linnaeus, 1758), is of high economical value in Turkey and its biological characteristics have hitherto not been studied in the South-western Black Sea. The purpose of this study was to determine the age and growth, length-weight relation, condition factor, sex ratio, age and length at first maturity, and reproduction period of the turbot in the south-western Black Sea coast of Turkey.

Materials and methods. Turbots were collected monthly in the south-western Black Sea coast of Turkey using bottom trawl and turbot gillnets. The fish samples were obtained between October 2004 and September 2005.

Results. A total of 264 turbots were sampled and the age groups ranged from I to X (no individuals found at age group IX). Total lengths were between 14.0 and $70.0 \mathrm{~cm}$, while weights varied from 34 to $5550 \mathrm{~g}$. The length-weight relation for combined sexes was determined as $W=0.0085 L^{3.1581}$. The von Bertalanffy growth equation parameters were: $L_{\infty}=73.55 \mathrm{~cm}, k=0.17$ year $^{-1}, t_{0}=-0.12$ year. The observed sex ratio (female : male) was $1: 0.35$. The length at first maturity $\left(L_{50}\right)$ of the species was $20.38 \mathrm{~cm}$ for females and $24.68 \mathrm{~cm}$ for males (both at two years old). Monthly gonadosomatic index (GSI) values suggest the spawning activity extends from 15 April to late June. Conclusion. The legal fishing season of the turbot, imposed in 2012, begins on 15 June. We recommend that this date should be postponed to 30 of June due to turbot's reproduction extending to late June.
\end{abstract}

Keywords: Turbot, age and growth, reproduction period, Black Sea

\section{INTRODUCTION}

The turbot, Scophthalmus maximus (Linnaeus, 1758), is a member of the family Scophthalmidae, a widely distributed family in the north-eastern Atlantic, including the Baltic Sea, Mediterranean Sea, and the Black Sea (Nelson 2006). Turbots inhabit sandy and rocky bottoms down to $70-80 \mathrm{~m}$, feeding mainly on fish, crustaceans and bivalves (Mengi 1971, Nielsen 1986). The turbot is one of the most expensive commercially captured fishes in Turkey. It occurs in coastal waters in the Black Sea, and grows up to $100 \mathrm{~cm}$ in total length, and $20 \mathrm{~kg}$ in body weight (Fischer et al. 1987). In the coastal waters of south-western Black Sea, it has been caught mainly by turbot gillnets at depths down to $50 \mathrm{~m}$ and otter trawls at depths greater than $50 \mathrm{~m}$ (Zengin and Düzgüneş 2003, Aydın and Şahin 2011).

Within 1964-1992, Turkey was the leading country in the Black Sea area in terms of turbot landings with a mean of 1991.1 t (71.26\%) (Prodanov 1997). Total landings of turbot decreased dramatically in 2002 to a mean of 428.71 $\mathrm{t}$ while it was $1983.3 \mathrm{t}$ between 1996 and 2001 (Anonymous 2014). In total, $209.4 \mathrm{t}$ of turbot were obtained in
2013 from Turkish seas comprising the south-western Black Sea, south-eastern Black Sea, Sea of Marmara, and north Aegean Sea. These waters yielded 118.6, 75.0, 14.4, and $1.4 \mathrm{t}$, respectively (Anonymous 2014).

Turbot, Scophthalmus maximus has been a target species in marine aquaculture for several European countries due to its high economical value (Kohno et al. 2001). A number of researchers carried out studies on the age and growth relation of turbot (Szlakowski 1990, Robert and Vianet 1988, Arneri et al. 2001, Caputo et al. 2001, Suzuki et al. 2001, Zengin et al. 2006), while others studied the reproductive biology of the species (Arneri et al. 2001, Caputo et al. 2001, Stankus 2001, 2003, Aydın and Şahin 2011). Studies on broodstock management were conducted by Hara et al. (2002) and Başaran and Samsun (2004), while the larval and juvenile developmental stages of the species were investigated by Moteki et al. (2001) and Türker et al. (2006). The effects of different stocking densities on growth performance were evaluated by Aksungur et al. (2007). The one study on the turbot stock assessment was carried out by Avşar (1999). 
The purpose of the presently reported study was to determine the biological characteristics of a declining population turbot from the south-western Black Sea coasts of Turkey. This survey covered the age and growth, lengthweight relation, condition factor, sex ratio, first maturity age and length, and reproduction period and it was the first such investigation from this area.

\section{MATERIALS AND METHODS}

Specimens of turbot, Scophthalmus maximus, were collected monthly with bottom trawl and turbot gillnets (165 mm mesh size; single-walled tangle nets) along the continental shelf area of the south-western Black Sea coast of Turkey between October 2004 and September 2005. Total length (TL) and body weight $(W)$ were determined on fresh samples to the nearest $0.1 \mathrm{~mm}$ and $0.1 \mathrm{~g}$, respectively.

The length-weight relation was calculated by the equation

$$
W=a L^{b}
$$

where $W$ is the total body weight [g], $L$ is the total length [cm], and $a$ and $b$ are coefficients (Le Cren 1951). Analysis of covariance was performed to test for differences in the length-weight relations between sexes (Zar 1999). Difference in mean length and weight between sexes was tested with $t$-test.

The Allometric Condition Factor $(\mathrm{K})$ was calculated using the equation given by Lima-Junior et al. (2002), modified from Fulton's (1902) formula:

$$
K=\left(W \cdot L^{-b}\right) \cdot 100
$$

where $W$ is the total weight, $L$ is the total length, and $b$ is the allometric regression coefficient.

Sex and maturation were determined firstly by visual gonad examination. Especially the sex of young individuals was confirmed by means of binocular microscope and the others by gross (macroscopic) examination. Sex ratio was compared through chi-squared analysis with an expected ratio of $1: 1$. The gonads were removed and weighed to the nearest $0.0001 \mathrm{~g}$. The monthly gonadosomatic index (GSI) values of male and female individuals were calculated with the following formula from Wootton (1998):

$$
\mathrm{GSI}=100 W_{\mathrm{G}} \cdot W^{-1}
$$

where $W_{\mathrm{G}}$ is the gonad weight, and $W$ is the total weight.

The maturity stages of the gonads were determined following the seven-point scale for flatfishes proposed by Witthames (2003): 1 = juvenile, 2 = developing virgin/ resting spent, $3=$ ripening $1,4=$ ripening $2,5=$ ripe, $6=$ running, $7=$ spent. To estimate lengths at $50 \%$ maturity $\left(L_{50}\right)$, a logistic function was fitted to the proportion of the mature individuals by size class using a nonlinear regression from King (2007):

$$
P=1 \cdot\left(1+e^{\left[-r\left(\mathrm{TL}-L_{50}\right)\right]}\right)^{-1}
$$

where $P$ is the proportion mature in each size class, $r$ is the slope of the curve, TL is the total length, and $L_{50}$ is the mean of total length at sexual maturity of the sampled turbots. $L_{50}=a \cdot r^{-1}$, where $a$ is an intercept.

Sagittal otoliths were removed, cleaned, and stored dry in small polyethylene bags for age determination. Age was estimated by counting presumptive annual growth rings on otoliths. The otoliths were immersed first in ethanol (70\%) and then in glycerine and xylol solution about $5 \mathrm{~min}$ and examined with binocular microscope under reflected light over a black background (Uysal 1992). Otoliths were read at least twice. After determination of ages, fishes were categorized in age groups and classified by their lengths with 5 -cm intervals.

Length at age was described by the von Bertalanffy growth model:

$$
L_{t}=L_{\infty}\left(1-e^{-k\left(t-t_{0}\right)}\right)
$$

where $L_{t}$ is the length at age $t, L_{\infty}$ is the predicted asymptotic length, $k$ is the growth coefficient, and $t_{0}$ is the age at 'zero' length (von Bertalanffy 1938). The formula was estimated with the first VIII age groups due to extreme deviation observed on the length-age curve associated with the lack of individuals in the IX and X year classes.

Growth performance index ( $\varphi^{\prime}$, phi-prime) was used for comparing fish growth in length (Pauly and Munro 1984):

$$
\varphi^{\prime}=\log _{10} k+2 \log _{10} L_{\infty}
$$

All statistical analyses and graphics were prepared with the MS Excel.

\section{RESULTS}

Length-frequency distribution. A total of 264 turbot individuals were collected with a total length ranging from 14.0 to $70.0 \mathrm{~cm}$, and total body weight from 34 to $5550 \mathrm{~g}$. The mean total length and weight of each presumptive age group are given in Table 1.

The mean total length and weight of females were higher than males. No significant difference was observed in mean length and weight between sexes $(P>0.05)$.

Table 1

Total length and weight values of presumptive age groups of turbot, Scophthalmus maximus, from the south-western coasts of Black Sea, Turkey

\begin{tabular}{cccc}
\hline Age & $n$ & TL $[\mathrm{cm}]$ & $W[\mathrm{~g}]$ \\
\hline I & 21 & $15.76 \pm 1.7$ & $55.71 \pm 24.1)$ \\
II & 143 & $21.28 \pm 2.8$ & $138.51 \pm 61.4)$ \\
III & 54 & $29.55 \pm 3.8$ & $388.40 \pm 179.0)$ \\
IV & 28 & $42.70 \pm 4.9$ & $1321.00 \pm 420.6)$ \\
V & 11 & $52.65 \pm 1.1$ & $2416.30 \pm 272.6)$ \\
VI & 3 & $56.13 \pm 0.6$ & $3116.67 \pm 236.3)$ \\
VII & 2 & $59.40 \pm 0.0$ & $3500.00 \pm 0.0)$ \\
VIII & 1 & 61 & 4100.00 \\
X & 1 & 70 & 5550.00 \\
\hline
\end{tabular}

Values are mean \pm standard deviation (where applicable); $n=$ number of specimens studied. 
Age composition and sex ratio. The presumptive age of Scophthalmus maximus varied between I and X years. The age group II $(54.17 \%)$ was dominant in both sexes, followed by age III (20.45\%), IV (10.61\%), I (7.95\%), V (4.17\%), VI (1.14\%), VII (0.76\%), VIII (0.38\%), and X $(0.38 \%)$ age groups. The age-length key for turbot is presented in Table 2, which shows a considerable range in length for each age group.

A total of 195 females (73.86\%) and 69 males (26.14\%) were used in the reproductive biology study. The sex ratio of female to male was $1: 0.35$. The chi-square test showed that there was a significant difference in the sex ratio $(P$ $<0.05$ )

Growth. The von Bertalanffy growth parameters were computed as $L_{\infty}=73.55 \mathrm{~cm}, k=0.17$ year $^{-1}, t_{0}=-0.12$ years for all samples. The growth curve is shown in Fig. 1. 6.82 .

The estimated growth performance index $\left(\varphi^{\prime}\right)$ was

Length-weight relation. ANCOVA did not detect a significant sex-based difference in the length-weight relation of Scophthalmus maximus $(P>0.05)$.

The equation for combined sexes was:

$$
W=0.0085 L^{3.1581}\left(n=264, R^{2}=0.989\right)
$$

The length-weight curve of the samples is presented in Fig. 2. The exponent $b>3$ indicates a positive allometric growth characteristic.

Condition factors. Monthly mean values of condition factor $(K)$ are presented in Fig. 3. The highest value occurred in May (0.95) and the lowest value in March (0.80) in the south-western Black Sea.

Gonad development and spawning period. A total of 264 turbots, consisting of 195 females (73.86\%) and 69 males $(26.14 \%)$ were used in the study.

Mean monthly GSI values were highest from May to June and the lowest from September to April (Fig. 4). Ac- cording to the gonadosomatic index (GSI), the reproduction period for this species in the south-western Black Sea extended from early May to mid or late June, when the water temperature was $12.5^{\circ} \mathrm{C}$ (Eryilmaz unpublished).

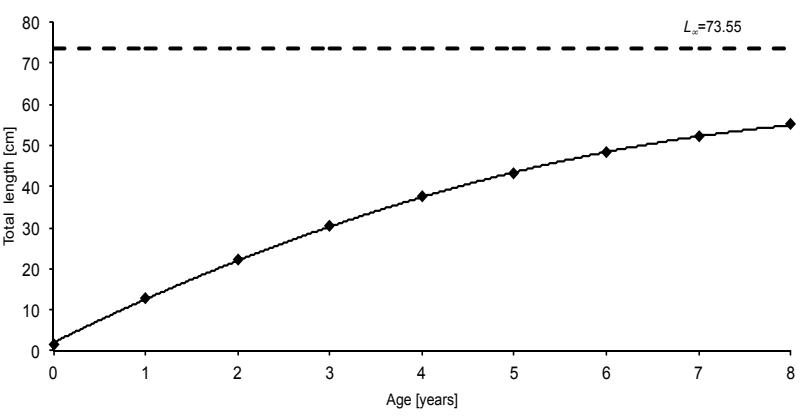

Fig. 1. The von Bertalanffy growth curve fitted by length at age data of turbot, Scophthalmus maximus, from the south-western coasts of Black Sea, Turkey $(n=263)$

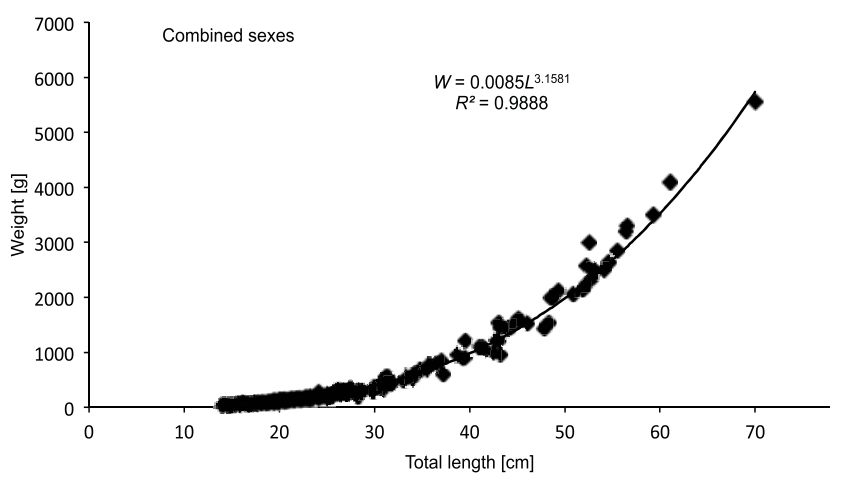

Fig. 2. The length-weight relation for combined sexes of turbot, Scophthalmus maximus, from the south-western coasts of Black Sea, Turkey

Table 2

Age-length key for females and males of turbot, Scophthalmus maximus, from the south-western coasts of Black Sea, Turkey, based on otolith readings

\begin{tabular}{|c|c|c|c|c|c|c|c|c|c|c|c|c|c|c|c|c|c|c|c|c|c|c|c|}
\hline \multirow{3}{*}{$\begin{array}{l}\text { Total length } \\
{[\mathrm{cm}]}\end{array}$} & \multicolumn{23}{|c|}{ Age group } \\
\hline & \multicolumn{2}{|c|}{ I } & \multicolumn{2}{|c|}{ II } & \multicolumn{2}{|c|}{ III } & \multicolumn{2}{|c|}{ IV } & \multicolumn{2}{|c|}{ V } & \multicolumn{2}{|c|}{ VI } & \multicolumn{2}{|c|}{ VII } & \multicolumn{2}{|c|}{ VIII } & \multicolumn{2}{|c|}{ IX } & \multicolumn{2}{|c|}{$X$} & \multicolumn{3}{|c|}{ Total } \\
\hline & $\mathrm{F}$ & $\mathrm{M}$ & $\mathrm{F}$ & M & $\mathrm{F}$ & M & $\mathrm{F}$ & M & $\mathrm{F}$ & M & $\mathrm{F}$ & M & $\mathrm{F}$ & $\mathrm{M}$ & $\mathrm{F}$ & $\mathrm{M}$ & $\mathrm{F}$ & M & $\mathrm{F}$ & $\mathrm{M}$ & $\mathrm{F}$ & $\mathrm{M}$ & $n$ \\
\hline $14.0-18.9$ & 17 & 2 & 25 & 5 & & & & & & & & & & & & & & & & & 42 & 7 & 49 \\
\hline $19.0-23.9$ & 1 & 1 & 59 & 26 & 1 & 1 & & & & & & & & & & & & & & & 61 & 28 & 89 \\
\hline $24.0-28.9$ & & & 15 & 13 & 19 & 7 & & 1 & & & & & & & & & & & & & 34 & 21 & 55 \\
\hline $29.0-33.9$ & & & & & 14 & 3 & & & & & & & & & & & & & & & 14 & 3 & 17 \\
\hline $34.0-38.9$ & & & & & 7 & 2 & 1 & 2 & & & & & & & & & & & & & 8 & 4 & 12 \\
\hline $39.0-43.9$ & & & & & & & 10 & 2 & & & & & & & & & & & & & 10 & 2 & 12 \\
\hline $44.0-48.9$ & & & & & & & 9 & 2 & & & & & & & & & & & & & 9 & 2 & 11 \\
\hline $49.0-53.9$ & & & & & & & & 1 & 8 & 1 & & & & & & & & & & & 8 & 2 & 10 \\
\hline $54.0-58.9$ & & & & & & & & & 2 & & 3 & & & & & & & & & & 5 & 0 & 5 \\
\hline $59.0-63.9$ & & & & & & & & & & & & & 2 & & 1 & & & & & & 3 & 0 & 3 \\
\hline $64.0-68.9$ & & & & & & & & & & & & & & & & & & & & & 0 & 0 & 0 \\
\hline $69.0-73.9$ & & & & & & & & & & & & & & & & & & & 1 & & 1 & 0 & 1 \\
\hline Total & 18 & 3 & 99 & 44 & 41 & 13 & 20 & 8 & 10 & 1 & 3 & 0 & 2 & 0 & 1 & 0 & 0 & 0 & 1 & 0 & 195 & 69 & 264 \\
\hline
\end{tabular}

$\mathrm{F}=$ females, $\mathrm{M}=$ males, $n=$ number of specimens studied. 
Size at first maturity was different between sexes, with females reaching maturity at a smaller size than males. The estimated value of $L_{50}$ was $20.38 \mathrm{~cm}$ for females and $24.68 \mathrm{~cm}$ for males (Fig. 5). The number of mature and immature samples in each size group is given in Fig. 6.

$$
\begin{gathered}
P_{\text {female }}=1 \cdot\left(1+e^{[-1.053(\mathrm{TL}-20.38)]}\right)^{-1} \\
P_{\text {male }}=1 \cdot\left(1+e^{[-0.6123(\mathrm{TL}-24.68]}\right)^{-1}
\end{gathered}
$$

The age at first maturity was estimated as 2 years for both sexes.

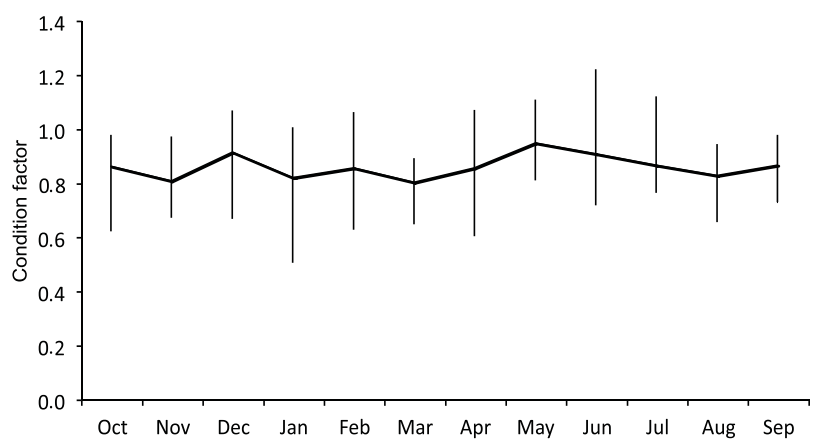

Fig. 3. Monthly fluctuation in the condition factors for combined sexes of turbot, Scophthalmus maximus from the south-western coasts of Black Sea, Turkey
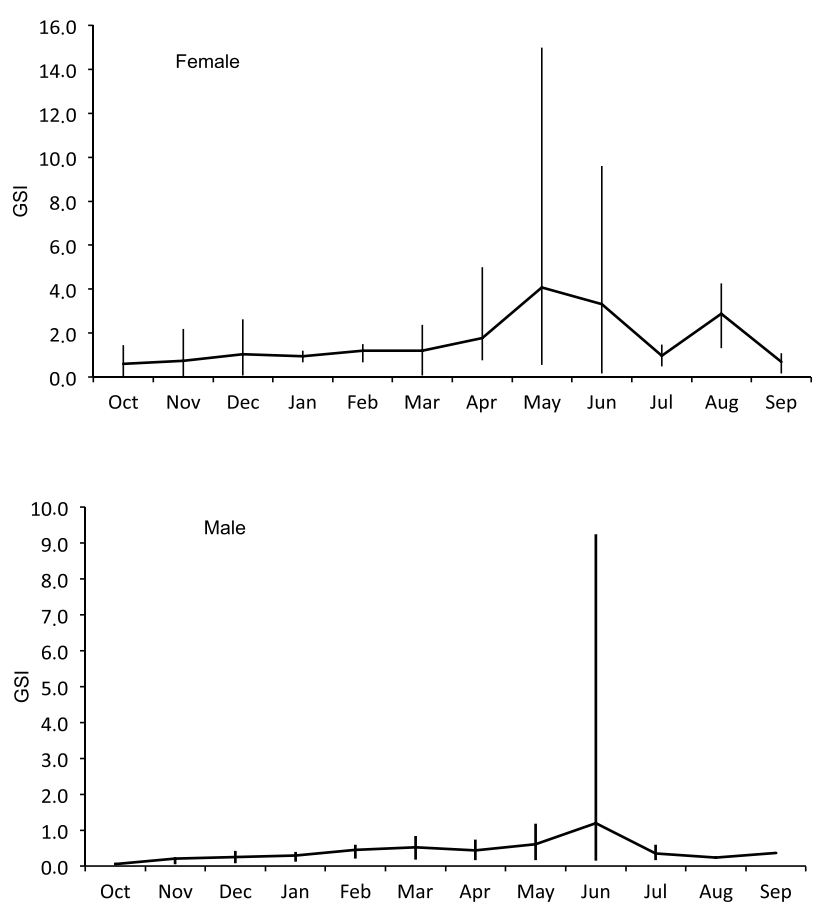

Fig. 4. Gonadosomatic index (GSI) values of female (1) and male (2) by month for turbot, Scophthalmus maximus, from the south-western coasts of Black Sea, Turkey; The error bars represent \pm standard deviation

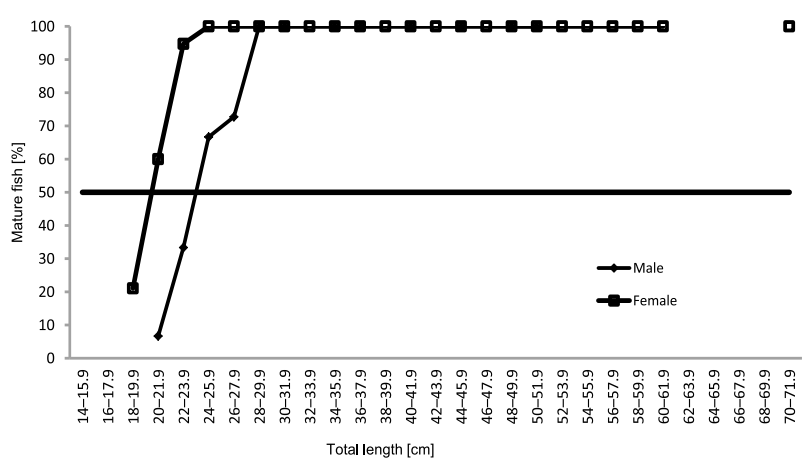

Fig. 5. Percentage of mature males and females of turbot, Scophthalmus maximus from the south-western coasts of Black Sea, Turkey in individual 2-cm length classes

\section{DISCUSSION}

It has been suggested that environmental conditions and fishing pressure are the main factors affecting the growth of fishes (Weatherley and Gill 1987). Different maximum lengths have been reported for turbot in the Black Sea such as $85 \mathrm{~cm}$ (Fischer et al. 1987) and $100 \mathrm{~cm}$ (Nielsen 1986). Szlakowski (1990) reported a maximum length of $48 \mathrm{~cm}$ for females and $32 \mathrm{~cm}$ for males in the Pomeranian Bay (Baltic Sea). The largest specimen measured in the Lithuanian waters of the Baltic Sea was 52.5 cm (Stankus 2001), although it should be noted that all marine fish attain smaller sizes in the this brackish-water see. Length values increased up to $70 \mathrm{~cm}$ in the Mediterranean and Black Sea. Caputo et al. (2001) and Arneri et al. (2001) determined the maximum length as $79 \mathrm{~cm}$ in the Adriatic Sea. Also, Zengin et al. (2006) determined a maximum length of $82 \mathrm{~cm}$ for the eastern Turkish coast of the Black Sea and mentioned that the female turbots are larger than the males. In this study, the maximum total length measured for females and males were $70 \mathrm{~cm}$ and $50.8 \mathrm{~cm}$, respectively. The most dominant age groups were the 2- and 3-year ages and the highest estimated age were 10 years for females and 5 years for males (Table 2). The maximum age was reported as 11 years on the eastern Black Sea (Suzuki et al. 2001, Zengin et al. 2006). Szlakowski (1990) studied 159 turbot samples and reported their maximum age as 9 (female) and 7 (male) in the Pomeranian Bay. However, Stankus (2001) stated that for total 720 turbots in the Baltic Sea (northern part of the Lithuanian zone), the maximum age among females was 16 years and males was 11 years. At the same time, for total 227 turbots in the Adriatic Sea, the maximum age was reported as 18 years by Arneri et al. (2001). These length and age values indicated that the Mediterranean and Black Sea populations of the turbot contain larger specimens than the Baltic Sea populations. Arneri et al. (2001) argued that the growth rate of turbot in the Adriatic Sea is slightly higher than in the North Sea and considerably higher than in the Baltic Sea and the north-western Mediterranean Sea due to higher temperature and food availability. 
The von Bertalanffy growth parameters showed that asymptotic length $\left(L_{\infty}=73.55 \mathrm{~cm}\right)$ was close to the largest fish and growth coefficient value $\left(k=0.17\right.$ year $\left.^{-1}\right)$ indicated slow attainment of maximal size such as the obtained values in studies achieved in the Black Sea (Table 3). Growth rates of the Baltic Sea turbot were slightly higher than the Black Sea turbot growth rates. In all of aforementioned regions, reasons for the differences in growth rates may be varied, caused by methodological differences in the age and growth studies, variation in temperature salinity, or differences in feeding habits. The result of Pauly and Munro (1984) growth performance index $\left(\varphi^{\prime}\right)$ value in the south-western Black Sea turbot is in accordance with those from other areas (Table 3 ). The $\varphi^{\prime}$ value was tested with values obtained from age and growth studies on turbot (Avsar 1998). It showed that there is no significant difference $(P>0.05)$ between the overall growth performances of the turbot sampled from the other areas.
The length-weight relation for combined sex Zengin et al. (2006) reported as:

$$
W=0.0112 L^{3.12}\left(n=1434, R^{2}=0.99\right)
$$

Şahin and Güneş (2011) as:

$$
W=0.0106 L^{3.1268}\left(R^{2}=0.973\right)
$$

and Arneri et al. (2001) as:

$$
W=0.011 L^{3.104}\left(n=155, R^{2}=0.99\right)
$$

These values are in accordance with our study, additionally, none of the length-weight relation studies of this species showed any differences between males and females.

The lowest estimated condition factor was in November (1.31) and the highest in May (1.62) as shown in Fig. 3. The peak in condition factor may be highly attributed to the filling gonads in May, but the fluctuations of the other month changes with abundance of the feed items (Le Cren 1951).

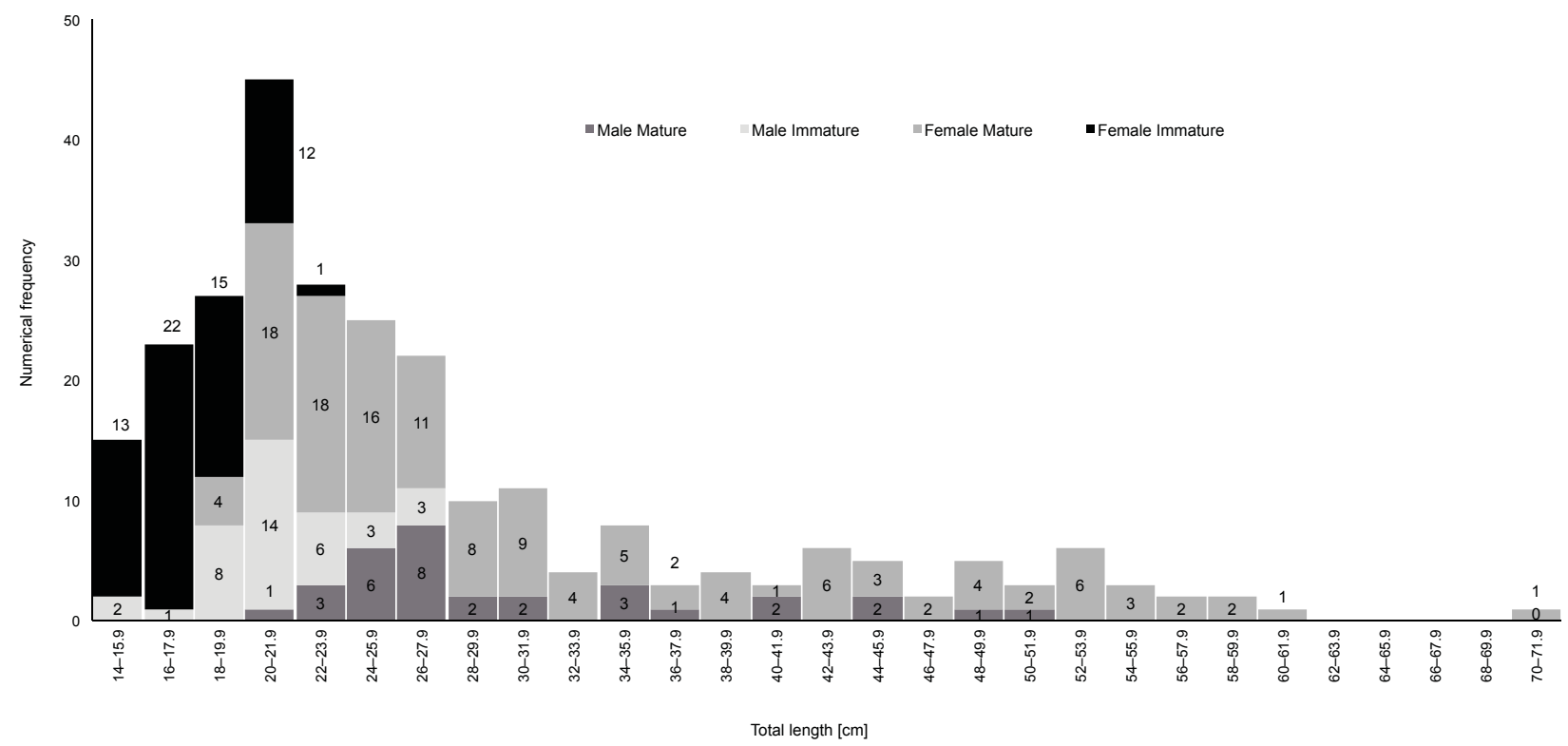

Fig. 6. Numbers of mature-immature individuals of turbot, Scophthalmus maximus, from the south-western coasts of Black Sea, Turkey, according to size groups in females and males

Table 3

A comparison of the growth parameters and growth performance indexes obtained from previous studies of turbot, Scophthalmus maximus

\begin{tabular}{lllcccc}
\hline \multicolumn{1}{c}{ Reference } & \multicolumn{1}{c}{ Location } & \multicolumn{1}{c}{ Sex } & $L_{\infty}$ & $k\left[\right.$ year $\left.{ }^{-1}\right]$ & $t_{0}$ & $\varphi^{\prime}$ \\
\hline Ivanov and Beverton 1985 & Black Sea, Romania & Combined & 87.2 & 0.125 & & 6.86 \\
Prodanov et al. 1997 & Black Sea, Ukraine & Combined & 77.1 & 0.130 & -0.881 & 6.65 \\
Szlakowski 1990 & Pomeranian Bay & Female & 51.9 & 0.200 & 0.296 & 6.30 \\
& & Male & 33.4 & 0.347 & 0.413 & 6.00 \\
Stankus 2001 & Baltic Sea & Female & 53.5 & 0,186 & 0.280 & 6.30 \\
& & Male & 35.0 & 0.301 & 0.350 & 5.91 \\
Arneri 2001 & Adriatic Sea & Female & 81.5 & 0.210 & -0.480 & 7.24 \\
& & Male & 66.2 & 0.310 & -0.140 & 7.21 \\
Suzuki et al. 2001 & S-E Black Sea & Female & 54.8 & 0.481 & -0.011 & 7.28 \\
& & Male & 45.0 & 0.597 & -0.011 & 7.10 \\
Zengin et al. 2006 & S-E Black Sea & Combined & 96.2 & 0.119 & -0.010 & 7.01 \\
This study & S-E Black Sea & Combined & 73.6 & 0.170 & -0.120 & 6.82 \\
\hline
\end{tabular}


The sex ratio varies from species to species, from population to another population and from year to year in the same population (Nikolsky 1963). The sex ratio was significantly female-biased $(1: 0.35)$. The ratio of males found in the study of Şahin and Güneş (2011) is more than two times of our value. The number of females is more than the number of males in all age groups, and VI, VII, VIII, and X age groups were exclusively female. The number of the individuals decreased with age.

The first maturity lengths $\left(L_{50}\right)$ calculated are $20.38 \mathrm{~cm}$ for females and $24.68 \mathrm{~cm}$ for males in the south-western Black Sea. It should be noted that we observed one mature male individual measured as $21.7 \mathrm{~cm}$ during laboratory studies in May. In the South-eastern Black Sea, the lengths at first maturity found were $38.8 \mathrm{~cm}$ (female) and $34.6 \mathrm{~cm}$ (male) (Zengin and Düzgüneş 2003). These values are higher than the ones obtained in this study. The presently reported study results and those of Zengin and Düzgüneş (2003) are incomparably different. The first maturity length of the turbot should be renewed with studies have more samples in the south Black Sea.

The first maturity age in both female and male turbots was estimated as 2 years. Various first maturity ages have been reported in the literature. Fischer et al. (1987) mentioned that the females reach maturity after the first 3-4 years. Ivanov and Beverton (1985) stated that turbots in Bulgarian-Romanian coasts reach sexual maturity in their 2nd year. Hara et al. (2002) indicated that natural spawning begins at 2 years of age in hatchery-bred stock at a water temperature of $14^{\circ} \mathrm{C}$. In Bulgarian waters, Prodanov and Mikhailov (2003) found the first maturity age as 3 years.

The GSI values indicate that the reproduction period of the turbot is from early May to mid or late June (Fig. 4). The reproductive period was reported by Slastenenko (1956) and Fischer et al. (1987) as March and June in the Black Sea while Nielsen (1986) mentioned that it was from April to August. In Ukrainian waters of the Black Sea, Gordina (1990) observed the spawning period extending from April to mid-June, and Shlyakhov and Charova (2003) found that it occurs from late March to late June. In Turkish waters of the Black Sea, Şahin and Güneş (2011) reported that the spawning takes place between April and June with a peak in May in the south-eastern Black Sea. In all studies carried out in the Black Sea, May and June are in the reproduction periods. According to Wootton (1998), temperature appears to be the most important factor among those that may influence the reproduction of fishes. Shlyakhov and Charova (2003) indicated that the water temperature needed for the spawning of the turbot is $8-12^{\circ} \mathrm{C}$. Also, we measured the water temperature as $12.5^{\circ} \mathrm{C}$ in May 2005. Thus, our finding is supporting this opinion.

In this study, the first maturity length was estimated for $20.38 \mathrm{~cm}$ for females and $24.68 \mathrm{~cm}$ for males, while minimum landing size of turbot, Scophthalmus maximus, in the Turkish waters of the Black Sea is $45 \mathrm{~cm}$ (Anonymous 2012). This significant difference in numbers will eliminate with comprehensive studies in the Black Sea. In fact that this situation is beneficial for the population.
Besides, fishing of turbot is banned between 15 April and 15 June since 2012. In our opinion, the fishing ban period should be extended to 30 June due to turbot reproduction extending to late June.

\section{ACKNOWLEDGEMENTS}

This study was supported by the Research Fund of the Istanbul University (Project No. 9/27082002). The authors thank to Suna TUZUN for correcting the English draft.

\section{REFERENCES}

Aksungur N., Aksungur M., Akbulut B., Kutlu İ. 2007. Effects of stocking density on growth performance, survial and food conversion ratio of turbot (Psetta maxima) in the net cages on the southeastern coast of the Black Sea. Turkish Journal of Fisheries and Aquatic Sciences 7 (2): 147-152.

Anonymous 2012. 2012-2016 Balıkçılık döneminde denizlerde ve iç sularda ticari balık yakalama sirküleri. [The commercial fish catching regulations in seas and inland waters in 2012-2016 fishing period.] Genelge No. 2012/68. Türkiye Cumhuriyeti Tarım ve Köyişleri Bakanlığı, Koruma ve Kontrol Genel Müdürlüğü, Ankara. [Circular No. 2012/68. Republic of Turkey. Minister of Agriculture and Rural Affair, General Directorate of Conservation and Inspection, Ankara, Turkey] 108 pp. [In Turkish.]

Anonymous 2014. Balıkçılık istatistikleri. [Fisheries Statistics.] Türkiye İstatistik Kurumu, Ankara, Turkey. http://tuik.gov.tr [In Turkish.]

Arneri E., Colella S., Giannetti G. 2001. Age determination and growth of turbot and brill in the Adriatic Sea: Reversal of the seasonal pattern of otolith zone formation. Journal Applied Ichthyology 17 (6): 256-261. DOI: 10.1046/j.1439-0426.2001.00293.x

Avşar D. (ed.) 1998. Balıkçılık Biyolojisi ve Populasyon Dinamiği. [Fisheries biology and population dynamics]. Adana Nobel Kitabevi, Adana, Turkey. [In Turkish.]

Avşar D. 1999. Türkiye'nin Doğu Karadeniz kıyılarındaki kalkan balığı (Scophthalmus maximus (Linnaeus, 1758)) stoku'nun incelenmesi. [Identification of turbot (Scophthalmus maximus) stock along the Turkish Black Sea coast.] Turkish Journal of Zoology 23 (EK1): 207-213. [In Turkish.]

Aydın İ., Şahin T. 2011. Reproductive performance of turbot (Psetta maxima) in the southeastern Black Sea. Turkish Journal of Zoology 35 (1): 109-113.

DOI: $10.3906 /$ zoo-0905-26

Başaran F., Samsun N. 2004. Survival rates of Black Sea turbot (Psetta maxima maeotica, L. 1758) broodstock captured by gill nets from different depths and their adaptation culture conditions. Aquaculture International 12 (3): 321-331. DOI: 10.1023/B:AQUI.0000036183.39217.2a

Caputo V., Candi G., Colella S., Arneri E. 2001. Reproductive biology of turbot (Psetta maxima) and brill (Scophthalmus rhombus) (Teleostei, Pleuronecti- 
formes) in the Adriatic Sea. Italian Journal Zoology 68 (2): 107-113.

DOI: 10.1080/11250000109356393

Fischer W., Bauchot M.-L., Schneider M. (eds.) 1987. Fiches FAO d'idendification des espéces pour les besoins de la pêche. (Revision 1), Mediterraneé et mer Noire, Zone de Pêche 37, 2, Vertébres, FAO, Rome, 761-1530.

Fulton T.-W. 1902. The rate of growth of fishes. 20th Annual Report of the Fishery Board of Scotland 1902 (3): 326-446.

Gordina A.D. 1990. O nereste kambaly-kalkana - Psetta maeotica (Pallas) (Scophthalnidae, Pisces) v Černom more v mae - iûne 1987 r. ["On the spawning of Psetta maeotica (Pallas) (Scophthalnidae, Pisces) in the Black Sea in May-June, 1987".] Èkologiâ morâ [Ekologiya Morya] 35: 40-43. [In Russian.]

Hara S., Özongun M., Güneş E., Ceylan B. 2002. Broodstock rearing and spawning of Black Sea turbot, Psetta maxima. Turkish Journal of Fisheries and Aquatic Sciences 2 (1): 9-12.

Ivanov L., Beverton R.J.H. 1985. The fisheries resources of the Mediterranean. Part 2. FAO Studies and Reviews. No. 60. FAO, Rome.

King M.G. 2007. Fisheries biology, assessment and management. Fishing News Book, 2nd edn. Blackwell Publishing, Oxford, UK.

Kohno H., Moteki M., Yoseda K., Şahin T., Üstündağ C. 2001. Development of swimming and feeding functions in larval turbot, Psetta maxima, reared in the laboratory. Turkish Journal of Fisheries and Aquatic Sciences 1 (1): 7-15.

Le Cren E.D. 1951. The length-weight relationship and seasonal cycle in gonad weight and condition in the perch (Perca fluviatilis). Journal Animal Ecology 20 (2): 201-219.

Lima-Junior S.E., Cardone I.B., Goitein R. 2002. Determination of a method for calculation of Allometric Condition Factor of fish. Acta Scientiarum, Maringá 24 (2): 397-400.

Mengi T. 1971. Türkiye denizlerinde yaşayan yassı balıklar ve populasyonları. Die plattfische und ihre populationen in den Türkischen küstengewassern. İstanbul Üniversitesi Fen Fakültesi mecmuası seri B 36 (1-2): 53-70. [In Turkish.]

Moteki M., Yoseda K., Sahin T., Üstündağ C., Kohno H. 2001. Transition from endogenous to exogenous nutritional sources in larval Black Sea turbot Psetta maxima. Fisheries Science 67 (4): 571-578. DOI: 10.1046/j.1444-2906.2001.00292.x

Nelson J.S. 2006. Fishes of the world. 4th edn. Wiley, New York, NY, USA.

Nielsen J.G. 1986. Scophthalmidae. Pp. 1287-1293. In: Whitehead P.J.P., Bauchot M.-L., Hureau J.-C., Nielsen J., Tortonese E. (eds.) Fishes of the North-eastern Atlantic and the Mediterranean. Vol. 3. UNESCO, Paris.

Nikolsky G.V. 1963. The ecology of fishes. Academic Press, London, UK.
Prodanov K., Mikhailov K. 2003. Status of demersal fish along the Bulgarian Black Sea coasts. Pp. 35-48. In: Öztürk B., Karakulak S. (eds.) Workshop on Demersal Resources in the Black Sea and Azov Sea. 15-17 April Şile, Istanbul-Turkey.

Prodanov K., Mikhailov K., Daskalov G., Maxim C., Chashchin A., Arkhipov A., Shlyakhov V., Ozdamar E. 1997. Environmental management of fish resources in the Black Sea and their rational exploitation. Studies and Reviews. General Fisheries Council for the Mediterranean. No. 68. FAO, Rome.

Pauly D., Munro J.L. 1984. Once more on the comparison of growth in fish and invertebrates. Fishbyte ICLARM 2 (1): 21.

Robert F., Vianet R. 1988. Age and growth of Psetta maxima (Linné, 1758) and Scophthalmus rhombus (Linné, 1758) in the Gulf of Lion (Mediterranean). Journal Applied Ichthyology 4 (3): 111-120. DOI: $10.1111 /$ j.1439-0426.1988.tb00550.x

Shlyakhov V., Charova I. 2003. The status of the demersal fish populations along the Black Sea coast of Ukraine. Pp. 65-74. In: Öztürk B., Karakulak S. (eds.) Workshop on Demersal Resources in the Black Sea and Azov Sea. 15-17 April Şile, Istanbul, Turkey.

Slastenenko E. 1956. Karadeniz havzası balıkları. [The fishes of the Black Sea basin.] Et ve Balık Kurumu Yayınlarından, İstanbul, Turkey. [In Turkish.]

Stankus S. 2001. Growth of turbot (Psetta maxima L.) in the northern part of the Lithuanian Economic Zone in the Baltic Sea. Acta Zoologica Lituanica 11 (4): $357-$ 365.

DOI: $10.1080 / 13921657.2001 .10512471$

Stankus S. 2003. The peculiarities of turbot (Psetta maxima L.) biology and their role in the ecosystem of the Baltic Sea coastal zone of Lithuania. Acta Zoologica Lituanica 13 (2): 217-238.

DOI: $10.1080 / 13921657.2003 .10512564$

Suzuki N., Kondo M., Gunes E., Ozongun M., Ohno A. 2001. Age and growth of turbot Psetta maxima in the Black Sea, Turkey. Turkish Journal of Fisheries and Aquatic Sciences 1 (1): 43-51.

Szlakowski J. 1990. Growth of Psetta maxima (Linnaeus, 1758) from the Gulf of Pomerania. Acta Ichthyologica et Piscatoria 20 (1): 13-28.

Şahin T., Güneş E. 2011. A preliminary study on population characteristics of turbot, Psetta maxima, in the eastern Black Sea, Turkey. Turkish Journal of Science and Technology 6 (1): 1-9.

Türker A. 2006. Effects of feeding frequency on growth, feed consumption, and body composition in juvenile turbot (Psetta maxima Linnaeus, 1758) at low temperature. Turkish Journal of Veterinary Animal Sciences 30 (2): 251-256.

Uysal A. 1992. Doğu Karadeniz (Sinop-Hopa) Bölgesi mezgit balığının Merlangius merlangus euxinus (Nordmann 1840) biyolojisi ve populasyon dinamiği. [Biology and population dynamics of the eastern Black Sea regions whiting Merlangius merlangus eu- 
xinus (Nordmann, 1840)]. İstanbul Üniversitesi Deniz Bilimleri ve Coğrafya Enstitüsü: bülten 9: 145-173. [In Turkish.]

von Bertalanffy L. 1938. A quantitative theory of organic growth (inquiries of growth laws II). Human Biology 10 (2): 181-213.

Weatherley A.H., Gill H.S. 1987. The biology of fish growth. Academic Press, London, UK.

Witthames P. 2003. Methods to assess maturity and realised fecundity illustrated by studies on Dover sole Solea solea. Pp. 125-137. In: Kjesbu O.S., Hunter J.R., Witthames P. (eds.) Reports of the workshop modern approaches to assess maturity and fecundity of warm and cold-water fish and squids. Institute for Marine Research, Bergen. Fisken Og Havet, Bergen, Norway.

Wootton R.J. 1998. Ecology of teleost fishes. 2nd edn. Fish and fisheries series. Vol. 24. Kluwer, Dordrecht, The Netherlands.
Zengin M., Düzgünes E. 2003. Variations on the turbot (Scophthalmus maeoticus) stocks in the south-eastern Black Sea during the last decade and comments on fisheries management. Pp. 9-26. In: Öztürk B., Karakulak S. (eds.) Workshop on Demersal Resources in the Black Sea \& Azov Sea. 15-17 April Şile, Istanbul, Turkey.

Zengin M., Gumuş A., Bostancı D. 2006. Age and growth of the Black Sea turbot, Psetta maxima (Linnaeus, 1758) (Pisces: Scophthalmidae), estimated by reading otoliths and by back-calculation. Journal Applied Ichthyology 22 (5): 374-381.

DOI: $10.1111 /$ j.1439-0426.2006.00743.x

Zar J.H. 1999. Biostatistical analysis. Prentice Hall, Upper Saddle River NJ, USA.

Received: 10 October 2014

Accepted: 5 March 2015

Published electronically: 30 June 2015 